\title{
B cell activation factor (BAFF) is a novel adipokine that links obesity and inflammation
}

\author{
Yu-Hee Kim ${ }^{1}$, Bong-Hyuk Choi ${ }^{1}$, \\ Hyae-Gyeong Cheon ${ }^{2}$ and Myoung-Sool Do ${ }^{1,3}$ \\ ${ }^{1}$ School of Life and Food Sciences \\ Handong Global University \\ Pohang 791-708, Korea \\ ${ }^{2}$ Center for Metabolic Syndrome Therapeutics \\ Drug Discovery Division \\ Korea Research Institute of Chemical Technology \\ Daejeon 305-343, Korea \\ ${ }^{3}$ Corresponding author: Tel, 82-54-260-1301; \\ Fax, 82-54-260-1319; E-mail, msdo @ handong.edu \\ DOI 10.3858/emm.2009.41.3.024
}

Accepted 18 November 2008 pression of TACl was distinct from that of BAFF-R and BCMA under TNF- $\alpha$ and BAFF ligand treatment. BAFF-R and BCMA expression levels were upregulated under pro-inflammatory conditions, but TACI was reduced. Conversely, BAFF-R and BCMA expression levels were downregulated by rosiglitazone treatment, but TACl was increased. Taken together, our results suggest that BAFF may be a new adipokine, representing a link between obesity and inflammation.

Keywords: adipokine; B-cell maturation antigen; obesity; rosiglitazone; TNFRSF13C protein, human; TNFSF13B protein, human; transmembrane activator and CAML Interactor protein

\section{Introduction}

B cell activation factor (BAFF) was recently introduced as a novel member of the TNF ligand superfamily and is also named BLyS, THANK, TALL-1, and TNFSF13B (Moore et al., 1999; Nardelli et al., 2001). BAFF is a type II transmembrane protein, containing 285 amino acids. The soluble form of BAFF, cleaved by "furin-like" protease, is a 152 amino acid protein, with a mass of 17,038 daltons (Moore et al., 1999). BAFF is produced by myeloid lineage cells, malignant $B$ cells, activated $\mathrm{T}$ cells, and bone marrow stromal cells (Nardelli et al., 2001; Novak et al., 2002; Scapini et al., 2003; Lavie et al., 2004). The recombinant soluble BAFF (aa 134-285) binds specifically to human primary $B$ cells and $B$ cell tumor lines, but not to T cells, monocytes, NK cells, or granulocytes (Moore et al., 1999).

BAFF has three receptors that belong to the TNF receptor superfamily: $\mathrm{B}$ cell maturation antigen (BCMA), transmembrane activator and CAML interactor (TACl), and BAFF receptor (BAFF-R) (Gross et al., 2000; Thompson et al., 2001). These receptors are primarily expressed in $B$ cells, but $\mathrm{TACl}$ and BAFF-R are known to be expressed by $\mathrm{T}$ cell subsets as well (Huard et al., 2001; $\mathrm{Ng}$ et al., 2004). Because of the receptor distribution, the studies on BAFF have been focused on $B$ cells and $T$ cells. It has been shown that BAFF is responsible for $B$ cell survival and maturation (Mackey et al., 1999; Craxton et al., 2003), and also functions as a T-cell co-stimulatory molecule (Huard et al., 2001; Ng et al., 2004). Furthermore, overexpre- 
ssion of BAFF results in autoimmune-like manifestations (Mackey et al., 1999), and BAFF levels are elevated in human autoimmune diseases such as systemic lupus erythematosus, rheumatoid arthritis, and multiple myeloma (Zhang et al., 2001; Novak et al., 2004; Seyler et al., 2005). The expression and functional effects of BAFF on other cell lineages have not been elucidated.

Adipose tissue has long been known to provide energy storage for the body, but recent studies have resulted in redefinition of this tissue as an endocrine organ (Mohamed-Ali et al., 1998). Adipose tissue causes inflammation by secreting cytokines (such as TNF- $\alpha$ and IL-6), chemokines (CCL2; MCP-1), and acute-phase molecules (CRP, haptoglobin, SAA, PAl-1) (Fantuzzi et al., 2005; $\mathrm{Kim}$ et al., 2006). Moreover, the adipokines, specific cytokines that are mainly produced by adipocytes e.g. leptin, adiponectin, and resistin, are increasingly being shown to have important roles as mediators linking the adipose tissue and inflammation (Fantuzzi et al., 2005; Kim et al., 2006; Tilg et al., 2006). Obesity, now considered to be a low-grade chronic inflammation state, increases the risk of many metabolic diseases such as type 2 diabetes, atherosclerosis, certain cancers, and autoimmune diseases (Wisse et al., 2004; Fantuzzi et al., 2005; Kim et al., 2006; Tilg et al., 2006). The dysregulation of adipokine secretion is often observed in patients with obesity; therefore, adipokines may provide a link between obesity and metabolic disorders. In this regard, further research into the identification and characterization of novel adipokines will improve our understanding of obesity and related diseases.

Previously, we have investigated the expression profiles of inflammatory genes in human SGBS adipocytes using DNA microarrays, and found that TNFSF13B (another term for BAFF) is also expressed by human adipocytes. We reported that TNFST13B expression is increased during adipocyte differentiation and TNF- $\alpha$ treatment (Do et al., 2006). Recently, Pelekanou and his coworkers have reported the expression of BAFF in breast tumor lesions and also in adipocytes surrounding the tumor lesions (Pelekanou et al., 2008). We were therefore interested in further examination of BAFF expression in adipocytes.

In adipocytes, secreted TNF acts on cells via an autocrine/paracrine pathway through TNFR1 activation (Nguyen et al., 2005). Additionally, it has been reported that $B A F F$ and $B A F F$ receptors are co-expressed by $B$ cells, and that BAFF may signal through an autocrine pathway as a member of the TNF ligand superfamily (Haiat et al., 2006). Therefore, verification of the existence of BAFF receptors on adipocytes may lead to a greater understanding of the function of BAFF in adipocytes.

Here we provide the first report of the expression of BAFF and BAFF receptors in 3T3-L1 adipocytes. We examined mRNA and protein expression levels of BAFF during adipocyte differentiation, and their changes under pro-inflammatory and anti-inflammatory conditions. We also examined the existence of BAFF receptors on 3T3-L1 adipocytes and observed their changes in response to induction or inhibition of inflammation. BAFF and BAFF receptor expression in adipose tissue of ob/ob transgenic
A

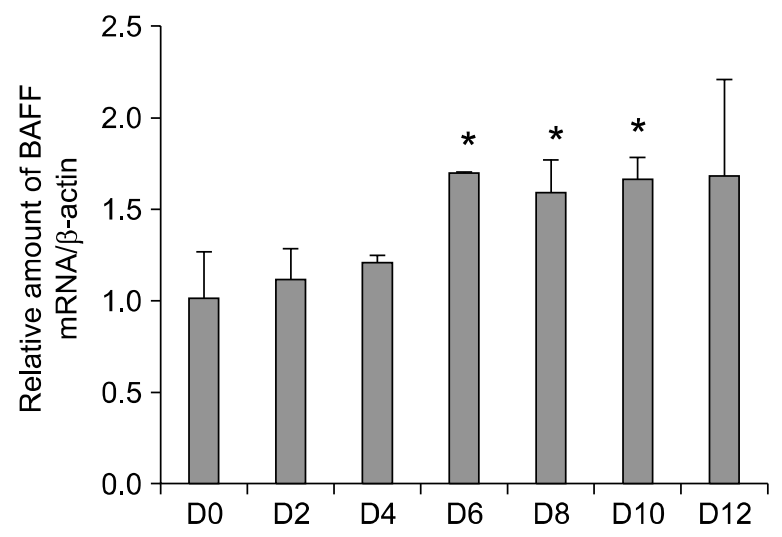

B

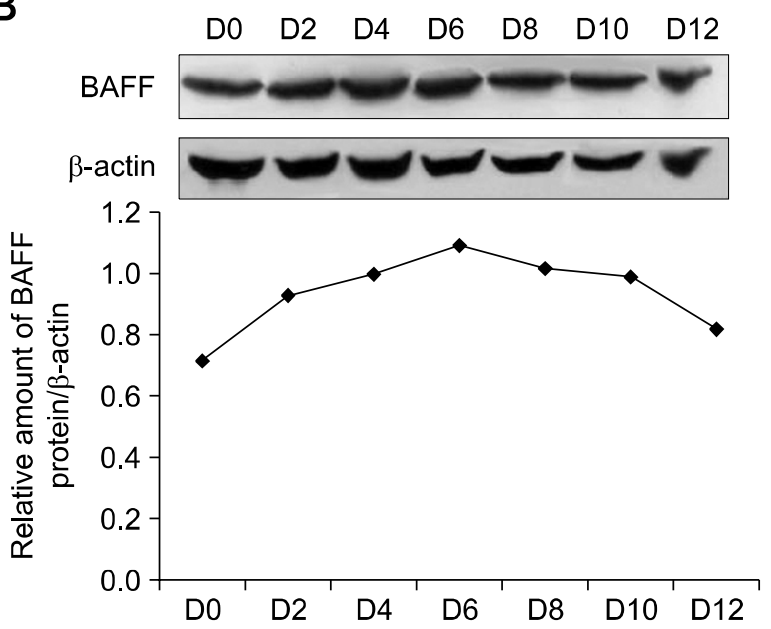

Figure 1. BAFF expression during adipocyte differentiation. (A) The relative amount of BAFF gene expression was evaluated by real time RT-PCR on every other day of 3T3-L1 adipocyte differentiation $\left({ }^{*} P<0.05\right)$. (B) The relative amount of BAFF protein was evaluated by western blot analysis on every other day of 3T3-L1 adipocyte differentiation. Data are expressed relative to untreated control cells and represent means \pm S.E. Experiments were conducted twice, each included triplication. 
mice was examined as well. We further investigated the autocrine effects on 3T3-L1 adipocytes by treatment with soluble BAFF protein and examined the changes of BAFF receptors expression.

\section{Results}

\section{BAFF expression is increased during adipocyte differentiation}

In order to determine whether BAFF expression is affected by adipocyte differentiation, we collected
3T3-L1 adipocytes on every other day during the progression of differentiation. We examined mRNA and protein expression levels of BAFF using real time RT-PCR and western blot analysis, respectively. BAFF mRNA expression levels were increased as differentiation progressed, and were augmented 1.7-fold after six days of differentiation (Figure 1A). Similarly, protein expression levels were increased in accordance with differentiation, and on day six of differentiation BAFF protein level was 1.5-fold higher than before the induction of differentiation (Figure 1B).
A

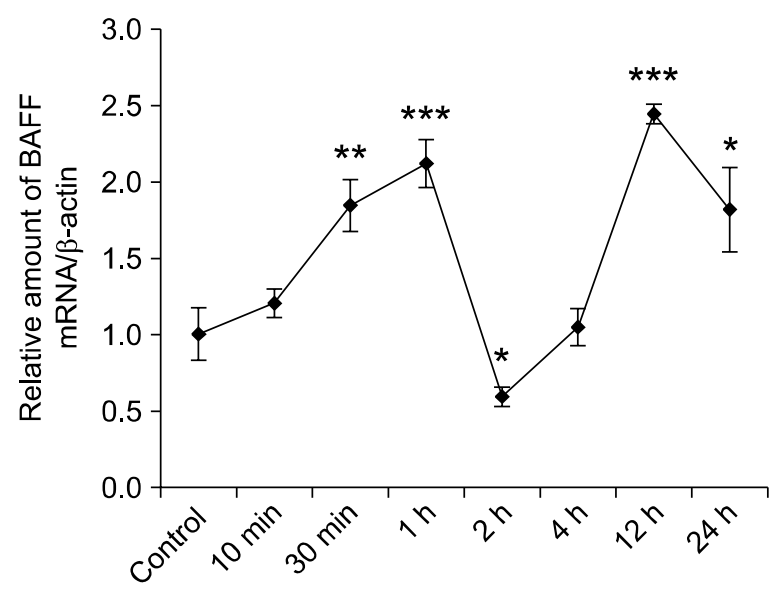

B

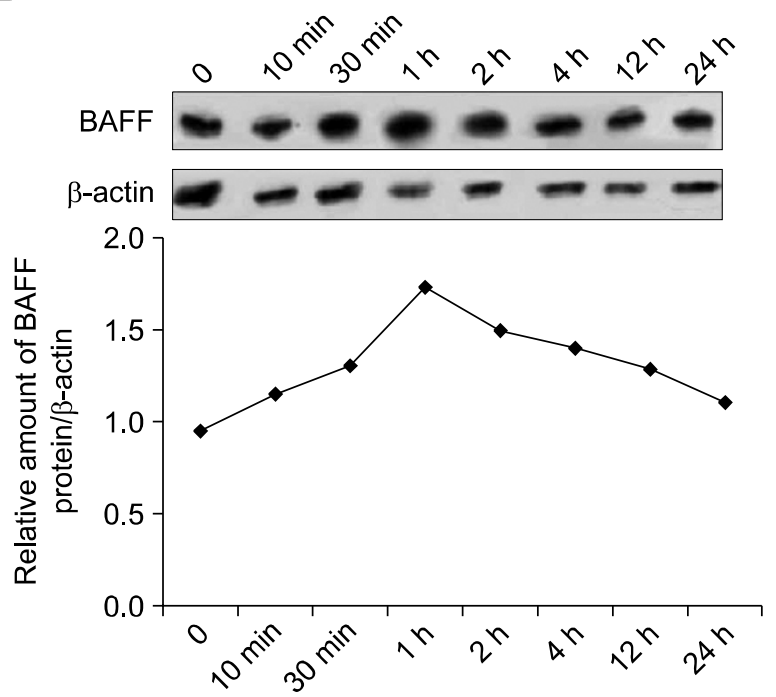

C

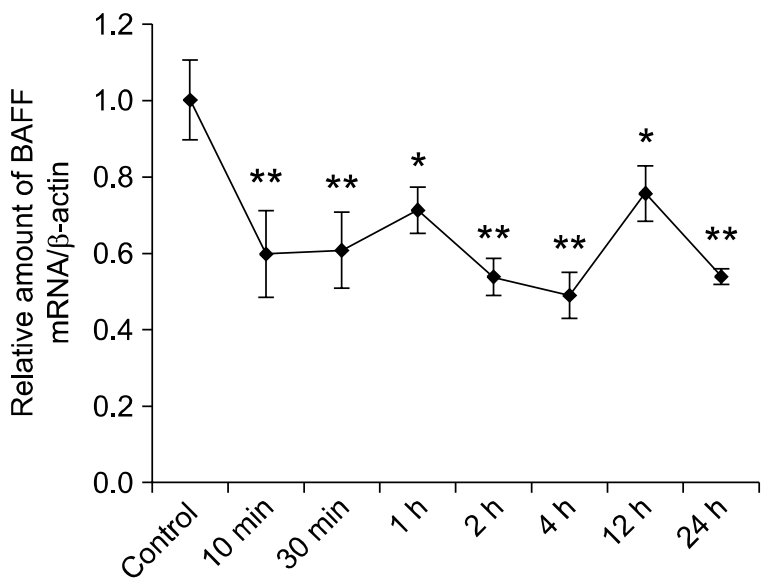

D
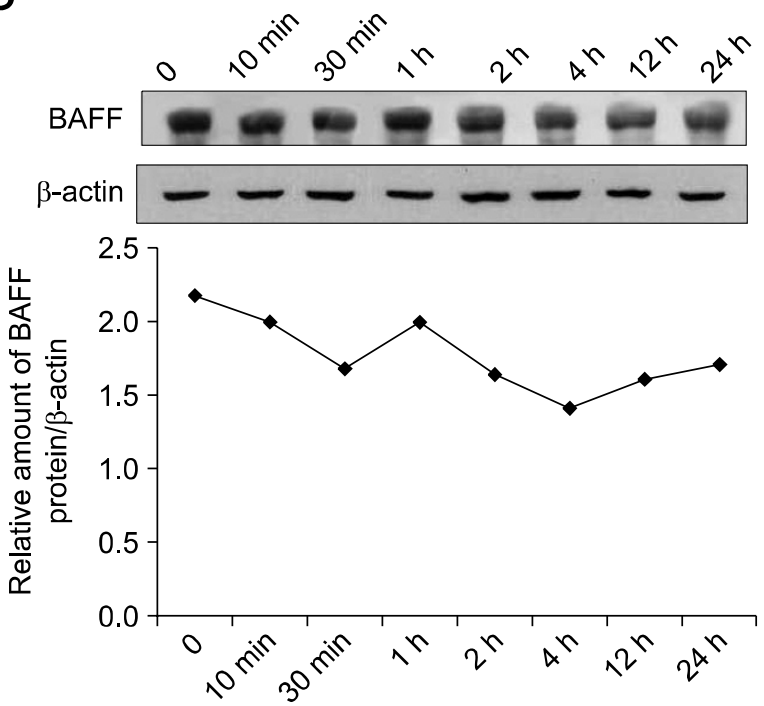

Figure 2. Changes of BAFF expression by TNF- $\alpha$ and Rosiglitazone treatment. (A) The relative amount of BAFF gene expression was evaluated by real time RT-PCR at different time points after simulation with $10 \mathrm{ng} / \mathrm{ml} \mathrm{TNF}-\alpha\left({ }^{*} P<0.05,{ }^{* *} P<0.01,{ }^{* * *} P<0.001\right)$. (B) The relative amount of BAFF protein was evaluated by western blot analysis at different time points after simulation with $10 \mathrm{ng} / \mathrm{ml}$ TNF- $\alpha$. (C) The relative amount BAFF gene expression was evaluated by real time RT-PCR at different time points after simulation with $1.5 \mu \mathrm{M}$ Rosiglitazone $\left({ }^{*} P<0.05,{ }^{* *} P<0.01\right)$. (D) The relative amount of BAFF protein was evaluated by western blot analysis at different time points after simulation with $1.5 \mu \mathrm{M}$ Rosiglitazone. Data are expressed relative to untreated control cells and represent means \pm S.E. Experiments were conducted twice, each included triplication. 


\section{Changes of BAFF expression under pro- and anti-inflammatory conditions}

In order to know whether BAFF expression is altered under inflammatory conditions, we applied TNF- $\alpha$ to fully differentiated 3T3-L1 adipocytes at a concentration of $10 \mathrm{ng} / \mathrm{ml}$ for $10 \mathrm{~min}, 30 \mathrm{~min}, 1 \mathrm{~h}, 2$ $\mathrm{h}, 4 \mathrm{~h}, 12 \mathrm{~h}$, and $24 \mathrm{~h}$. We isolated mRNA and protein from adipocytes and measured BAFF expression levels using real time RT-PCR and western blot analysis. The overall expression of BAFF
mRNA was upregulated by TNF- $\alpha$ treatment. Although the expression was diminished after 2-4 $\mathrm{h}$ of treatment, it was greatly increased by long-term treatment with TNF- $\alpha$ (Figure 2A). As Figure 2B shows, BAFF protein expression was slightly increased as well. The expression peaked after $1 \mathrm{~h}$ of treatment and then it steadily decreased, however the overall expression was increased from $20 \%$ to $80 \%$ by TNF- $\alpha$.

Furthermore, in order to investigate changes in
A

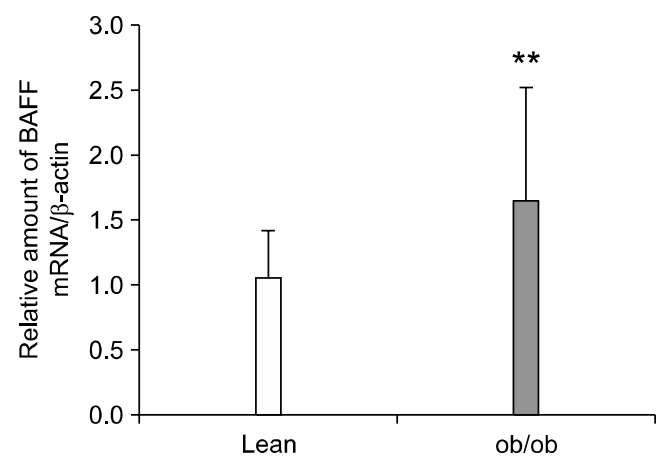

B
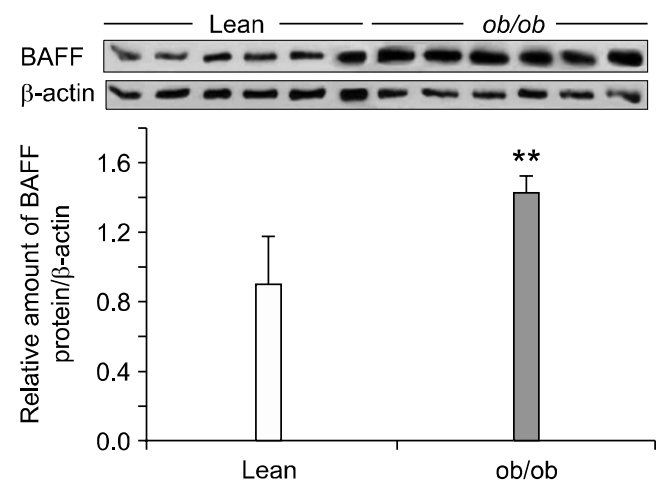

C

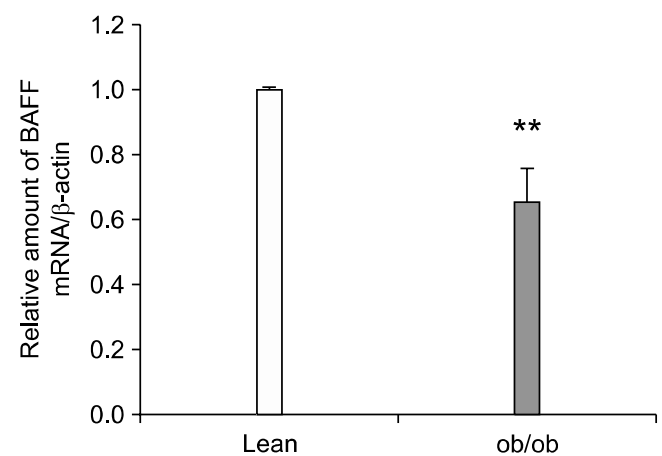

D

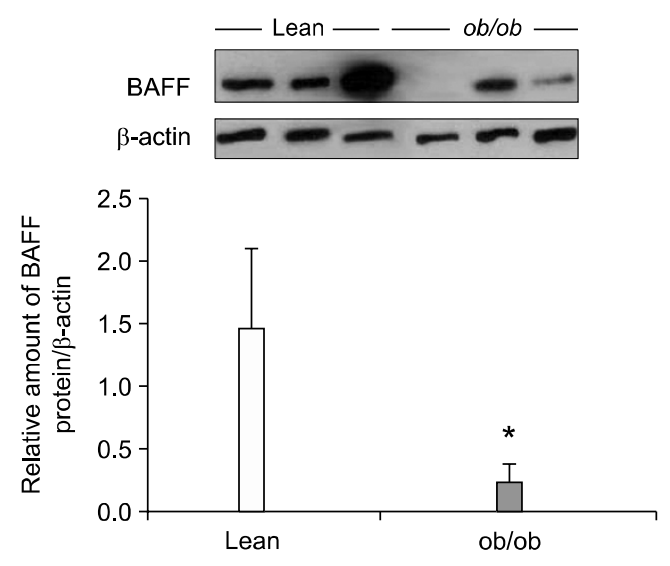

E

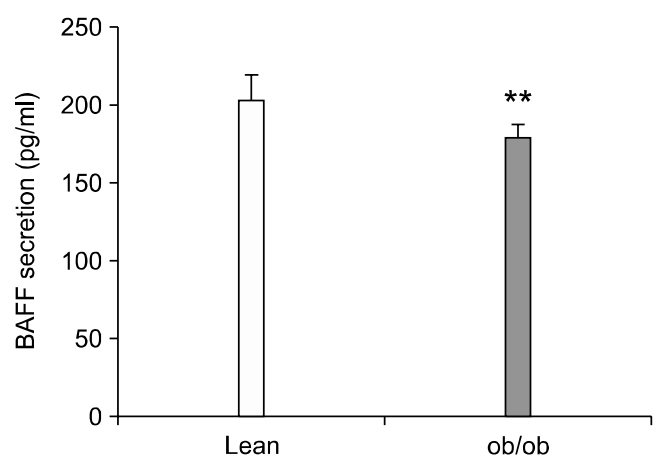

Figure 3. BAFF expression in ob/ob mice. The relative amount of (A) BAFF mRNA in EAT by real time RT-PCR, (B) BAFF protein in EAT by western blot analysis, (C) BAFF mRNA in VAT by real time RT-PCR, and (D) BAFF protein in VAT by western blot analysis were evaluated in lean and ob/ob transgenic mice. (E) BAFF protein levels in mouse serum detected by ELISA. Data are expressed relative to lean mice and represent means \pm S.E. Experiments were conducted twice, each included triplication $\left(n=6\right.$ per group, $\left.{ }^{*} P<0.05,{ }^{* \star} P<0.01\right)$. 
BAFF expression after inhibition of inflammation, we treated 3T3-L1 adipocytes with $1.5 \mu \mathrm{M}$ of Rosiglitazone. We treated the fully differentiated adipocytes with Rosiglitazone for $10 \mathrm{~min}, 30 \mathrm{~min}, 1 \mathrm{~h}, 2$ $\mathrm{h}, 4 \mathrm{~h}, 12 \mathrm{~h}$, and $24 \mathrm{~h}$. We isolated mRNA and protein from these adipocytes and BAFF expression was examined using real time RT-PCR and western blot analysis. BAFF mRNA expression was reduced roughly $30-45 \%$ under anti-inflammatory conditions (Figure 2C). BAFF protein expression was decreased by Rosiglitazone treatment as Figure 2D shows.

\section{BAFF expression and secretion in $o b / o b$ transgenic mice}

BAFF expression appears to be upregulated during adipocyte differentiation and under induced inflammation. We also investigated BAFF expression in an animal model. We dissected epididymal adipose tissue (EAT) from lean control mice and $o b / o b$ transgenic mice, and extracted total mRNA and protein. We then examined BAFF expression using real time RT-PCR and western blot analysis. Consistent with our hypothesis, we found that BAFF mRNA expression was increased 1.6-fold in obese mice (Figure $3 A, n=6$ ), as was the protein expression level (Figure 3B, $n=6$ ). In visceral adipose tissue (VAT), however, mRNA and protein expression are larger in lean than obese (Figure $3 C, D)$. Secreted BAFF levels in mouse sera were quantified by ELISA and smaller amount of BAFF was detected in ob/ob mice sera (Figure $3 E$ ).

\section{Expression of BAFF receptors in 3T3-L1 adipocytes}

As a ligand, BAFF signals through three different membrane-bound receptors: BAFF-R, BCMA, and
A

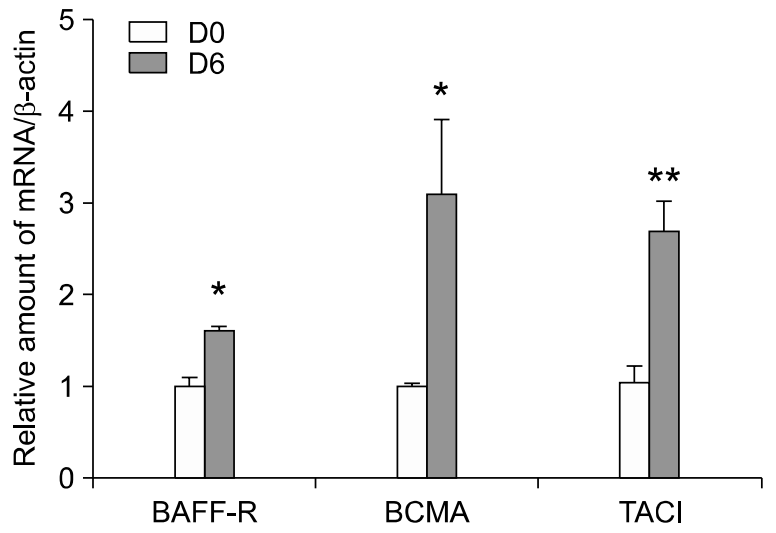

C

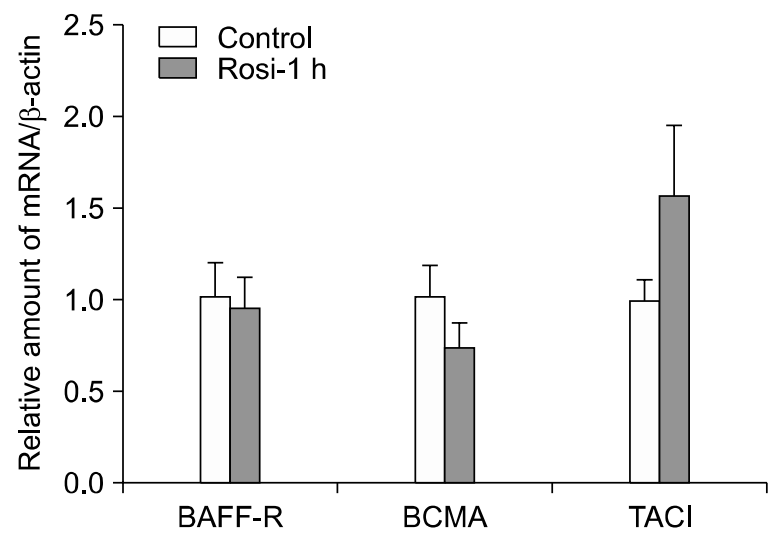

B

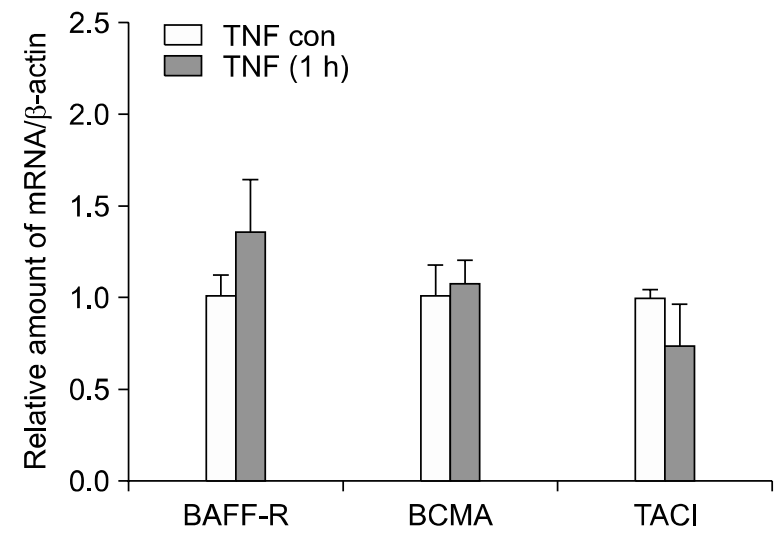

D

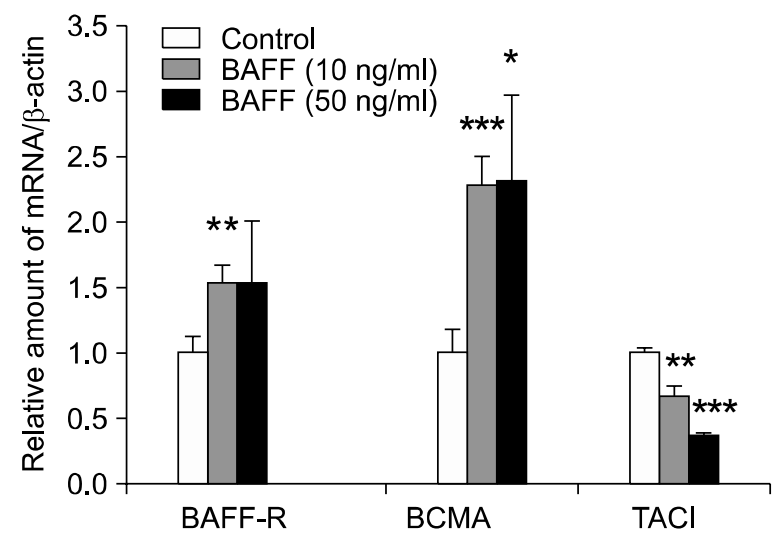

Figure 4. Changes of gene expression levels for BAFF receptors. The relative amounts of gene expression for BAFF receptors were evaluated by real time RT-PCR (A) in pre-adipocyte and fully differentiated adipocytes, (B) after $1 \mathrm{~h} \mathrm{TNF-} \alpha$ treatment, and (C) after $1 \mathrm{~h}$ Rosiglitazone treatment of fully differentiated adipocytes, and (D) after treatment with two different concentrations of recombinant BAFF. Data are expressed relative to untreated control cells and lean mice and represent means \pm S.E. Experiments were conducted twice, each included triplication $\left({ }^{*} P<0.05,{ }^{* *} P<0.01,{ }^{* * *} P<0.001\right)$. 
TACl. We sought to investigate the presence of BAFF receptors in 3T3-L1 adipocytes. First, we examined whether these three receptors are expressed in 3T3-L1 adipocytes using real time RT-PCR. We found that all three receptors are present in adipocytes.

We further verified the changes in expression of these receptors during adipocyte differentiation. Specifically, we assessed expression of the BAFF receptors on day six of differentiation, under inflammatory and anti-inflammatory conditions produced by TNF- $\alpha$ or Rosiglitazone treatment. Figure $4 \mathrm{~A}$ shows that expression of BAFF-R, BCMA, and TACl was increased 1.6-fold, 3-fold, and 2.7-fold, respectively, during adipocyte differentiation. After the induction of pro- and anti-inflammatory conditions, expression of the BAFF receptors was examined. According to Figure 2, one hour of treatment was most effective for both TNF- $\alpha$ and Rosiglitazone. We therefore chose the sample treated for one hour for analysis of gene expression levels by real time RT-PCR. As Figure 4B indicates, BAFF-R and $B C M A$ expression levels were upregulated under pro-inflammatory conditions, but TACl was reduced. Conversely, BAFF-R and BCMA expression levels were downregulated by Rosiglitazone treatment, but TACl was increased (Figure $4 \mathrm{C}$ ).

\section{Autocrine signaling of BAFF in 3T3-L1 adipocytes}

In order to investigate autocrine signaling of BAFF in adipocytes, we treated fully differentiated 3T3-L1 adipocytes with two different concentrations of recombinant BAFF $(10 \mathrm{ng} / \mathrm{ml}$ and $50 \mathrm{ng} / \mathrm{ml})$ for 24 $\mathrm{h}$. We examined changes in mRNA expression levels of BAFF receptors to determine which receptors are dominantly activated by BAFF. As Figure 4D shows, BAFF-R and BCMA expression levels are upregulated 1.5-fold and 2.3-fold respectively by TNFSF13B treatment. Conversely, $\mathrm{TACl}$ expression is downregulated.

\section{Discussion}

We previously reported the expression of inflammatory molecules in SGBS human adipocytes, including BAFF. BAFF was initially identified in B cells and was thought mainly to be secreted from myeloid cells. It was subsequently shown that BAFF is also expressed in adipocytes. We therefore sought to determine its expression pattern, and examine its role as a link between obesity and inflammation. In the current study, we verified the expression of BAFF in adipocytes and examined the changes in BAFF expression that occur under inflammatory and anti-inflammatory conditions.

During adipocytes differentiation, BAFF expression level was 1.5-fold augmented. Although it is not dramatically increased, its expression level was 2-fold more increased by inducing inflammation. BAFF mRNA expression was significantly increased by short-term stimulation with TNF- $\alpha$, but it was diminished after $2 \mathrm{~h}$ of treatment and again increased by long-term stimulation.

We used Rosiglitazone as an anti-inflammatory drug because it is a peroxisome proliferator- activated receptor-gamma (PPAR- $\gamma$ ) agonist which has anti-diabetic properties and potential anti- inflammatory effects as recent studies have shown (Sánchez-Hidalgo et al., 2005; Koufany et al., 2008). Currently, Kolak and her collogues have reported that chronic Rosiglitazone therapy altered gene expression involved in fatty acid synthesis and inflammation (Kolak et al., 2007). It indicates Rosiglitazone potentially affects both obesity and inflammation.

TNF- $\alpha$ signals through the autocrine loop, so the presence of BAFF receptors on adipocytes suggests an autocrine mechanism for BAFF. Thus, we treated differentiated adipoctyes with BAFF protein and found a reciprocal relationship in the expression patterns of TACl and BAFF-R and BCMA. While BAFF-R and BCMA expression was upregulated by the autocrine action of BAFF, TACl expression was downregulated. This expression pattern was the same under conditions of TNF- $\alpha$ stimulation.

BAFF-R is a principal receptor required for BAFFmediated mature $\mathrm{B}$ cell survival (Thompson et al., 2001), and it signals anti-apoptosis via NFKB and $\mathrm{Bcl}-2$ (Langat et al., 2008). TACl signaling activates NF-AT, AP-1, and NFKB (Gross et al., 2000). Recently, Sakurai reported that BAFF changes its receptor preference kinetically (Sakurai et al., $2007)$. In the early stage of $B$ cell activation, BAFF preferentially transmits the signal via BAFF-R. Subsequently, BAFF-R signaling upregulates $\mathrm{TACl}$ expression on the cell surface and $\mathrm{TACl}$ provides negative feedback against excess $B$ cell activation. Therefore, it is possible that TACI may also deliver a negative signal in adipocytes.

We got several interesting results from in vivo tests. BAFF mRNA and protein expression in EAT is greater in ob/ob mice, but it is reversed in VAT. It was interesting to see depot-specific differential expression of BAFF, but it is hard to make an explanation for it at this point. Instead, we have a need for further studies on cellular source of BAFF in different adipose tissues after fractionation into adipocytes and stromal/vascular cells since macrophages are infiltrated into adipose tissue in conse- 
quence of obesity (Weisberg et al., 2003). Moreover, in measurement of BAFF serum levels in lean and $o b / o b$ mice, BAFF secretion was surprisingly decreased in ob/ob mice which are resistant to the induction of autoimmune diseases. Autoimmunity in obesity is mainly mediated by leptin (La Cava et al., 2004). According to La Cava, leptin, which is produced by adipocytes that are present in the perilymphonodal adipose tissue, promotes the differentiation of $T_{H} 1$ cells and the secretion of pro-inflammatory cytokines (e.g. IFN- $\gamma$, TNF) while further inducing autoimmune diseases. In leptindeficient $o b / o b$ mice, increased production of $\mathrm{T}_{\mathrm{H}}$ 2-type cytokines (e.g. IL-4, IL-10) and reduced secretion of $T_{H} 1$-type cytokines were observed. These mice were resistant to the induction of autoimmune diseases (La Cava et al., 2004). It is very meaningful since overexpression of BAFF results in autoimmune-like manifestations (Mackey et al., 1999). The absence of leptin possibly has an inhibitory effect on BAFF secretion and accordingly resists autoimmunity. At the same time, soluble form of BAFF is secreted after membrane-bound form of BAFF is cleaved by protease at Golgi apparatus (Moore et al., 1999). Therefore, distribution of BAFF in cell and its condition for cleavage should be explored later. The BAFF expression and secretion level in diet-induced obesity should be thoroughly investigated in order to know a relationship between BAFF and autoimmune diseases.

In order to understand the role of BAFF as a new adipokine in relation to inflammation, a detailed study is needed. It would be interesting to block the expression of BAFF in adipocytes using siRNA, in order to study the significance of BAFF expression in adipocytes. Moreover, through studying ligand and receptor binding, we may be able to identify which receptor is solely responsible for BAFF signaling in adipocytes.

Taken together, our study shows the possibility that BAFF is a novel adipokine which may be a link between obesity and inflammation. This is the first report presenting the expression of BAFF in 3T3-L1 adipocytes.

\section{Methods}

\section{Materials}

DMEM, high-glucose DMEM, BCS, FBS, were purchased from Hyclon (Logan, UT). Trypin/EDTA, insulin, dexamethasone, and IBMX were purchased from Sigma-Aldrich (St. Louis, MO). Trizol for RNA extraction and Superscript II reverse transcriptase were purchased from Invitrogen (Carlsbad, CA). $2 \times$ SYBR Green Mix was purchased from AB Applied Bioscience (Foster City, CA). Primers for the PCR analysis were purchased from Bioneer (Daejeon,
Korea). Antibody against BAFF was purchased from R\&D Systems (Minneapolis, MN). Antibody against $\beta$-actin, antirat HRP-conjugated IgG, and anti-rabbit HRP-conjugated IgG were purchased from Cell Signaling Technology (Danvers, MA). Recombinant mouse TNF- $\alpha$ was purchased from Sigma-Aldrich (St. Louis, MO). Recombinant mouse BAFF was purchased from R\&D Systems (Minneapolis, MN). Rosiglitazone (Glaxo Smithkline, Brentford, MDX, UK) was kindly provided by Molecular Neurophysiology Lab., POSTECH, Korea.

\section{Cell culture and induction of adipocyte differentiation}

3T3-L1 pre-adipocytes purchased from ATCC (American Type Culture Collection, Manassas, VA) were cultured in DMEM containing $10 \%$ BCS at $37^{\circ} \mathrm{C}$ in a humidified atmosphere of $5 \% \mathrm{CO}_{2}$. After 3 or 4 days, cells were collected after reaching $90 \%$ confluence by $0.05 \%$ Trypsin $/ 0.53 \mathrm{mM}$ EDTA treatment. After centrifugation (1,300 rpm, $5 \mathrm{~min}$ ), cells were plated into 6 well plates at a density of $3 \times 10^{4}$ cell/well. At one day post-confluence (designated "day $0 "$ ), cell differentiation was induced with a mixture of $0.5 \mathrm{mM}$ of methylisobutylxanthine, $0.25 \mathrm{mM}$ of dexamethasone, and 5 $\mathrm{mg} / \mathrm{ml}$ of insulin in DMEM containing $10 \% \mathrm{FBS}$. On day two and thereafter, DMEM supplemented with $10 \%$ FBS and $5 \mathrm{mg} / \mathrm{ml}$ insulin was subsequently replaced every two days. 3T3-L1 adipocytes, seven to eight days post-differentiation, were treated with $10 \mathrm{ng} / \mathrm{ml} \mathrm{TNF}-\alpha$ or $1 \mu \mathrm{M}$ Rosiglitazone for $10 \mathrm{~min}, 30 \mathrm{~min}, 1 \mathrm{~h}, 2 \mathrm{~h}, 4 \mathrm{~h}, 12 \mathrm{~h}$, and $24 \mathrm{~h}$. Cells were exposed to $10 \mathrm{ng} / \mathrm{ml}$ or $50 \mathrm{ng} / \mathrm{ml}$ recombinant BAFF for $24 \mathrm{~h}$.

\section{Mice}

Six-week-old ob/ob transgenic mice and lean C57BL/6 mice were purchased from Central Lab. Animal Inc. (Seoul, Korea). Mice were fed standard chow diet until age eight wk. All mice were housed in cages on a 12-h day, 12-h night cycle, temperature $22 \pm 1{ }^{\circ} \mathrm{C}$, humidity $55 \pm 5 \%$. At the time of the experiments, mice were killed under anesthesia. Blood was collected in EDTA coated tubes and separated serum by centrifugation $(2,000 \mathrm{~g}, 20 \mathrm{~min})$. Epididymal adipose tissues were collected by dissection, weighed, quickly frozen by immediate immersion in liquid nitrogen and stored at $-70^{\circ} \mathrm{C}$ for RNA and protein isolation.

\section{Quantification of gene expression levels by real time RT-PCR}

Total RNA was isolated from 3T3-L1 adipocytes using Trizol reagent (Invitrogen, Carlsbad, CA). Cells were homogenized by passing four to five times through a 23 gauge needle. After approximately five min, samples were centrifuged for ten $\min$ at $4^{\circ} \mathrm{C}$, and $12,000 \mathrm{rpm}$. Supernatants were treated with chloroform and were mixed by vortexing for $15 \mathrm{~s}$. After centrifugation, the colorless fractions were transferred into new tubes. For precipitation of total RNA, samples were mixed with isopropyl alcohol. The RNA pellet was washed with $75 \%$ ethanol and dissolved in RNase free water. RNA quantification was measured by determining the absorbance at $260 \mathrm{~nm}$ in a spectrophotometer $\left(A_{260}\right)$. RNA samples were stored in a $-70^{\circ} \mathrm{C}$ 
deep-freezer. To prepare cDNA, total extracted RNA $(1 \mu \mathrm{g})$ was mixed with oligo dT primer and RNase free water. Samples were incubated in a thermocycler to denature the RNA and anneal the oligo dT primer. The reaction was mixed with $5 \times$ first strand buffer, $20 \mathrm{mM}$ of DTT, $10 \mathrm{mM}$ of dNTP mix, RNase free water and Superscript II reverse transcriptase. Mixtures were incubated in a thermocycler $\left(42^{\circ} \mathrm{C}\right.$ for $1 \mathrm{~h}$ and $72^{\circ} \mathrm{C}$ for $\left.7 \mathrm{~min}\right)$. Real time RT-PCR analysis was performed by Applied Biosystems 7500 Real Time PCR system (Applied Biosystems, Foster City, CA). Samples were mixed with $2 \times$ SYBR Green Mix (Applied Biosystems, Foster City, CA), $0.5 \mu \mathrm{M}$ of the appropriate primers, and cDNA, and were incubated in the Applied Biosystems 7500 Real Time PCR system for an initial denaturation at $94^{\circ} \mathrm{C}$ for $10 \mathrm{~min}$, followed by $40 \mathrm{PCR}$ cycles. Each cycle consisted of $95^{\circ} \mathrm{C}$ for $15 \mathrm{~s}$, followed by $60^{\circ} \mathrm{C}$ for $1 \mathrm{~min}$. To confirm amplification of specific transcripts, melting curve profiles (cooling the sample to $65^{\circ} \mathrm{C}$ for $15 \mathrm{~s}$ and heating slowly to $95^{\circ} \mathrm{C}$ with continuous measurement of fluorescence) were produced at the end of each PCR. Oligonucleotide primers were as follows: BAFF, 5'-GGCAGGTACTACGACCATCTC-3' and 5'-TGGGCCTTTTCTCACAGAAGT-3'; BAFF-R, 5'-CCCCAGACACTTCAGAAGGA-3' and 5'-AGGTAGGAGCTGAGGCATGA-3'; BCMA, 5'-ATCTTCTTGGGGCTGACCTT-3' and 5'-CTTTGAGGCTGGTCCTTCAG-3'; TACI, 5'-GTGTGGCCACTTCTGTGAGA-3' and 5'-CTGGTGCCTTCCTGAGTTGT-3'; and $\beta$-actin, 5'-AGCCATGTACGTAGCCATCC-3' and 5'TCCCTCTCAGCTGTGGTGGTGAA-3'.

\section{Quantification of protein expression levels by western blot analysis}

After experimental treatment, cells were washed twice with ice-cold PBS and lysed with extraction buffer containing 50 $\mathrm{mM}$ Tris- $\mathrm{HCl}(\mathrm{pH} 7.5), 150 \mathrm{mM} \mathrm{NaCl}, 1 \% \mathrm{NP}-40,1 \mathrm{mM}$ EDTA, $10 \mathrm{mM}$ sodium pyrophosphate, $1 \mathrm{mM}$ sodium orthovanadate, $100 \mathrm{mM} \mathrm{NaF}, 1 \mathrm{mM}$ PMSF and protease inhibitor cocktail, and stayed on ice for $30 \mathrm{~min}$. Insoluble materials were removed by centrifugation at $15,000 \mathrm{~g}$ for $10 \mathrm{~min}$ at $4^{\circ} \mathrm{C}$. The total concentration of extracted proteins was determined using the Bradford method. Total protein from dissected adipose tissue was isolated using homogenization buffer (50 mM Tris- $\mathrm{HCl}(\mathrm{pH} 8.0), 150 \mathrm{mM} \mathrm{NaCl}$, $5 \mathrm{mM}$ EDTA, 1\% NP-40, $1 \mathrm{mM}$ PMSF). Tissue was homogenized in 10 volumes of ice-cold homogenization buffer using glass homogenizer. After $10 \mathrm{~min}$ of incubation on ice, samples were centrifuged $\left(12,000 \mathrm{rpm}, 4^{\circ} \mathrm{C}, 20\right.$ $\min$ ) and supernatants were subjected to quantification using the Bradford method. The proteins in the supernatants were separated by $10 \%$ SDS-PAGE and transferred onto nitrocellulose membranes. After blocking for 1 $\mathrm{h}$ at room temperature with TBS-T (10 mM Tris, $150 \mathrm{mM}$ $\mathrm{NaCl}, 0.05 \%$ Tween-20, pH 7.6) containing $5 \%$ nonfat milk, the membranes were incubated with the appropriate primary antibodies. To detect the antigen-bound antibodies, the blots were treated with secondary antibodies conjugated to HRP. Immuno-reactivity was detected using the ECL western blotting detection system.

\section{Quantification of BAFF secretion in serum by ELISA}

Measurement of BAFF secretion in lean and ob/ob mice serum is performed with mouse BAFF/BLyS/TNFSF13B immunoassay (R\&D Systems, Quantikine) according to the manufacturer's instruction.

\section{Statistical analysis}

The data was analyzed by the ANOVA procedure of the Statistical Analysis System (SAS Institute, 1999-2001). Significant differences between groups were determined using Duncan's multiple range tests. Probability values of $>0.05$ were considered statistically not significant.

\section{Acknowledgements}

This work was supported by the Korea Research Foundation Grant funded by the Korean Government (MOEHRD, Basic Research Promotion Fund) (KRF-2007-521-C00300).

\section{References}

Craxton A, Magaletti D, Ryan EJ, Clark EA. Macrophage- and dendritic cell-dependent regulation of human B-cell proliferation requires the TNF family ligand BAFF. Blood 2003;101:4464-71

Do MS, Jeong HS, Choi BH, Hunter L, Langley S, Pazmany $L$, Trayhurn P. Inflammatory gene expression patterns revealed by DNA microarray anaysis in TNF- $\alpha$-treated SGBS human adipocytes. Yonsei Med J 2006;47:729-36

Fantuzzi G. Adipose tissue, adipokines and inflammation. J Allergy Clin Immunol 2005;115:911-9

Gross JA, Johnston J, Mudri S, et al. TACl and BCMA are receptors for a TNF homologue implicated in B-cell autoimmune disease. Nature 2000;404:995-9

Haiat S, Billard C, Quiney C, Ajchenbaum-Cymbalista F, Kolb JP. Role of BAFF and APRIL in human B-cell chronic lymphocytic leukaemia. Immunology 2006;118:281-92

Huard B, Schneider P, Mauri D, Tschopp J, French LE. T cell costimulation by the TNF ligand BAFF. J Immunol 2001; 167:6225-31

Kim YH, Choi BH, Do MS. The interaction of adipose tissue with immune system and related inflammatory molecules. Immune Network 2006;6:169-78

Kolak M, Yki-Järvinen H, Kannisto K, et al. Effects of chronic rosiglitazone therapy on gene expression in human adipose tissue in vivo in patients with type 2 diabetes. J Clin Endochrinol Metab 2007;92:720-4

Koufany M, Moulin D, Bianchi A, et al. Anti-inflammatory effect of antidiabetic thiazolidinediones prevents bone resorption rather than cartilage changes in experimental polyarthritis. Arthritis Res Ther 2008;10:R6

La Cava A, Matarese G. The weight of leptin in immunity. Nat Rev Immunol 2004;4:371-9

Langat DL, Wheaton DA, Platt JS, Sifers T, Hunt JS. Signaling pathways for B cell-activating factor (BAFF) and a proliferation-inducing ligand (APRIL) in human placenta. Am J Pathol 2008;172:1303-11 
Lavie F, Miceli-Richard C, Quillard J, Roux S, Leclerc P, Mariette X. Expression of BAFF (BLyS) in T cells infiltrating labial salivary glands from patients with Sjogren's syndrome. J Pathol 2004;202:496-502

Mackay F, Woodcock SA, Lawton P, et al. Mice transgenic for BAFF develop lymphocytic disorders along with autoimmune manifestations. J Exp Med 1999;190:1697-710

Mohamed-Ali V, Pinkney JH, Coppack SW. Adipose tissue as an endocrine and paracrine organ. Int J Obes Relat Metab Disord 1998;22:1145-58

Moore PA, Belvedere A, Orr K, et al. BLyS: member of the tumor necrosis factor family and B lymphocyte stimulator. Science 1999;285:260-3

Nardelli B, Belvedere O, Roschke A, et al. Synthesis and release of B-lymphocyte stimulator from myeloid cells. Blood 2001;97:198-204

$\mathrm{Ng}$ LG, Sutherland AP, Newton R, et al. B cell-activation factor belonging to the TNF family (BAFF)- $R$ is the principal BAFF receptor facilitating BAFF costimulation of circulating $T$ and B cells. J Immunol 2004;173:807-17

Nguyen MT, Satoh H, Favelyukis S, et al. JNK and tumor necrosis factor-alpha mediate free fatty acid-induced insulin resistance in 3T3-L1 adipocytes. J Biol Chem 2005;280: 35361-71

Novak AJ, Bram RJ, Kay NE, Jelinek DF. Aberrant expression of B-lymphocyte stimulator by B chronic lymphocytic leukemia cells: a mechanism for survival. Blood 2002; 100:2973-9

Novak AJ, Darce JR, Arendt BK, et al. Expression of BCMA, $\mathrm{TACl}$, and BAFF-R in multiple myeloma: a mechanism for growth and survival. Blood 2004;103:689-94
Pelekanou V, Kampa M, Kafousi M, et al. Expression of TNF-superfamily members BAFF and APRIL in breast cancer: immunohistochemical study in 52 invasive ductal breast carcinomas. BMC Cancer 2008;8:76-84

Sánchez-Hidalgo M, Martín AR, Villegas I, C. Alarcón De La Lastra. Rosiglitazone, an agonist of peroxisome proliferators-activated receptor gamma, reduces chronic inflammation in rats. Biochem Parmacol 2005;69:1733-44

Sakurai D, Kanno Y, Hase H, Kojima H, Okumura K, Kobata $\mathrm{T}$. TACl attenuates antibody production costimulated by BAFF-R and CD40. Eur J Immunol 2007:37:110-8

Scapini P, Nardelli B, Nadali G, et al. G-CSF stimulated neutrophils are a prominent source of functional. BLyS J Exp Med 2003;197:297-302

Seyler TM, Park YW, Takemura S, et al. BLyS and APRIL in rheumatoid arthritis. J Clin Invest 2005;115:3083-92

Thompson JS, Bixler AS, Qian S, et al. BAFF-R, a newly identified TNF receptor that specifically interacts with BAFF. Science 2001;293:2108-11

Tilg $\mathrm{H}$, Moschen AR. Adipokines: mediators linking adipose tissue, inflammation and immunity. Nat Rev Immunol 2006; 6:772-83

Weisberg SP, McCann D, Desai M, et al. Obesity is associated with macrophage accumulation in adipose tissue. J Clin Invest 2003;112:1796-808

Wisse B. The inflammatory syndrome: the role of adipose tissue cytokines in metabolic disorders linked to obesity. J Am Soc Nephrol 2004;15:2792-800

Zhang J, Roschke V, Baker KP, et al. Cutting edge: a role for $B$ lymphocyte stimulator in systemic lupus erythematosus. J Immunol 2001;166:6-10 